\title{
VLIV KOMBINACE VYSOKOPECNÍ JEMNĚ MLETÉ GRANULOVANÉ STRUSKY A INERTNIICH PŘÍMĚSÍ NA FYZIKÁLNĚ-MECHANICKÉ PARAMETRY BETONU
}

\author{
EFFECT OF THE COMBINATION OF BLAST-FURNACE FINELY \\ GROUND GRANULATED SLAG AND INERT ADMIXTURES ON \\ PHYSICAL-MECHANICAL PARAMETERS OF CONCRETE
}

\author{
Milan Meruňka ${ }^{*}, 1$, Rudolf Hela ${ }^{1}$
}

${ }^{*}$ merunka.m@fce.vutbr.cz

${ }^{1}$ Vysoké učení technické v Brně, Fakulta stavební, Ústav technologie stavebních hmot a dílců, Veveří 331/95, 602 00 Brno

\begin{abstract}
Abstrakt
Tato práce se zabývá kombinací vysokopecní jemně mleté granulované strusky (VJMGS) v optimálním poměru $\mathrm{s}$ příměsí inertní. Cílem této práce je oveřrit vliv vzájemné kombinace př́měsí na fyzikálně-mechanické parametry betonové směsi, konkrétně na pevnost betonu v tlaku. Získané výsledky naznačují, že i s poloviční dávkou VJMGS ve směsi se dají získat velmi obdobné fyzikálně-mechanické parametry betonu v porovnání s recepturou obsahující pouze VJMGS, což může být výhodné nejen z ekonomického hlediska, ale také z hlediska ekologického.
\end{abstract}

\section{Klíčová slova}

Vysokopecní jemně mletá granulovaná struska, inertní př́měsi, pevnost betonu v tlaku

\begin{abstract}
This paper deals with the combination of blast furnace finely ground granulated slag (VJMGS) in an optimal ratio with an inert admixture. The aim of this work is to verify the influence of the mutual combination of admixtures on the physical-mechanical parameters of the concrete mixture, specifically the compressive strength of concrete. The obtained results suggest that even with half the dose of VJMGS in the mixture it is possible to obtain very similar physical-mechanical parameters of concrete in comparison with the recipe containing only VJMGS, which can be advantageous not only from an economic point of view but also from an ecological point of view.
\end{abstract}

Key words

Ground Granulated Blast-furnace Slag, inert admixtures, compressive strength of concrete

\section{1 ÚVOD}

Z důvodu stále zvyšujícího se tlaku na výrobu směsných cementi̊, ekonomické náročnosti z důvodu mletí či uzavírání vysokých pecí a s tím související delší dopravní vzdálenosti, způsobují zhoršenou dostupnost, potažmo zvyšování ceny této suroviny. V případě čerstvé betonové směsi lze za pomoci VJMGS redukovat např́íklad riziko vzniku bleedingu, nebot' zrno vysokopecní jemně mleté granulované strusky disponuje velkým měrným povrchem a dobrou nasákavostí. V průběhu zrání betonu a jeho zatvrdlém stavu dochází vlivem latentní hydraulicity VJMGS k reakci s $\mathrm{Ca}(\mathrm{OH})_{2}$, přičemž dochází ke vzniku hydratačních produktů zahušt’ujících mikrostrukturu [1], což by v konečném důsledku mělo zvyšovat trvanlivost betonového kompozitu.

Hlavním cílem tohoto experimentu bylo zjistit vliv částečné náhrady VJMGS příměsí inertní v optimálním poměru mísení zajištujícím maximální hutnost matrice. Nejdůležitějším parametrem pro navržený způsob optimalizace dávkování prríměsí byla granulometrie jednotlivých vstupních př́měsí, díky čemuž byl stanoven jejich optimální poměr mísení s cílem dosáhnout maximální hutnosti jemných složek společně s cementem v suchém stavu. Dosažení maximální hutnosti betonového kompozitu by mělo vést ke zvýšení jeho trvanlivosti. 
Vlivem nižší porozity by mělo docházet např́iklad k nižšímu průniku chloridových iontů do struktury betonu, které způsobují korozi výztuže či průniku $\mathrm{CO}_{2}$ způsobujícího karbonataci betonu [2]. Zvýšení hutnosti cementové matrice vede zároveň i ke snížení pórovitosti kompozitu či tranzitních zón, což by se mělo pozitivně projevit na fyzikálně-mechanických parametrech kompozitu a zlepšení trvanlivosti při cyklickém zmrazování za prítomnosti vody či chemicky rozmrazovacích látek (CHRL). V konečném důsledku by se optimální kombinace príměsí mohla jevit výhodná nejen z ekologického, ale také z ekonomického hlediska, nebot' v důsledku zvýšení fyzikálně-mechanických parametrů by mohlo dojít ke snížení dávek cementu.

Inertní příměsi jsou dle EN 206+A2 [3] látky, které vzhledem ke svému chemickému či mineralogickému složení netuhnou či netvrdnou ani po přidání tzv. budiče. Většinou se jedná o látky, jejichž úkolem je zvýšit hutnost cementové matrice a modifikovat reologické vlastnosti betonu (zlepšit čerpatelnost či snížit riziko odlučivosti vody z betonu, tzv. bleedingu). Ačkoliv se mezi inertní příměsi řadí dle normy i mikromletý vápenec, $\mathrm{v}$ rámci mnoha experimentů byla prokázána tzv. skrytá aktivita vápenců [4], [5]. Jemné částice tvoří krystalizační zárodky, na které se mohou reakční produkty slínku vysrážet. Přítomnost těchto zárodků urychluje růst krystalů, vede k větší hydrataci slínku a ovlivňuje i fyzikálně-mechanické parametry kompozitu. Mezi další pozitiva tohoto druhu př́měsi se dá zařadit povrchová adsorpce vody. Ta je závislá zejména na měrném povrchu, který je dán jemností mletí. Obecně lze proto konstatovat, že se přidáním mikromletého vápence do betonové směsi snižuje riziko odlučivosti vody z betonu [6].

Další surovinou řadící se mezi inertní příměsi jsou kamenné odprašky (filler, moučka). Jedná se o jemné kamenné podíly vzniklé $\mathrm{v}$ lomech při drcení kameniva. Velikost částic se pohybuje v rozmezí 0,01 až $0,125 \mathrm{~mm}$ a jejich další vlastnosti jsou závislé na petrografickém druhu drcené suroviny. Nejen z důvodu velkého měrného povrchu, ale také z důvodu nepravidelného, ostrohranného tvaru zrn, je pak nutné při výrobě betonu použít vyšší množství záměsové vody. To však v konečném důsledku může způsobit zhoršení fyzikálně-mechanických parametrů a zároveň zvýšení rizika segregace kameniva či množství odloučené vody z betonové směsi.

\section{ANALÝZA VSTUPNÍCH SUROVIN}

Aby bylo možné provést správný návrh betonové směsi a poměr optimálního mísení, bylo nutné jednotlivé vstupní suroviny pečlivě analyzovat. Konkrétně se jednalo o VJMGS z elektrárny Dětmarovice (STR). Z inertních příměsí byly vybrány mikromleté vápence společnosti Carmeuse Mokrá číslo 7 (VÁP 7) a 9 (VÁP 9), které se vzájemně lišily jemností mletí. Dále byly vybrány dva kamenné fillery z odlišných lokalit, konkrétně z lomu Zárubka (ZAR) a Bílý Kámen (BK). V obou případech se jedná o granodiorit, tedy hlubinnou vyvřelou horninu s podstatným množstvím křemene. Na Obr. 1 je zachycena morfologie zrn jednotlivých vstupních příměsí za použití skenovacího elektronového mikroskopu (SEM). Tab. 1 udává základní vstupní parametry použitých př́měsí.
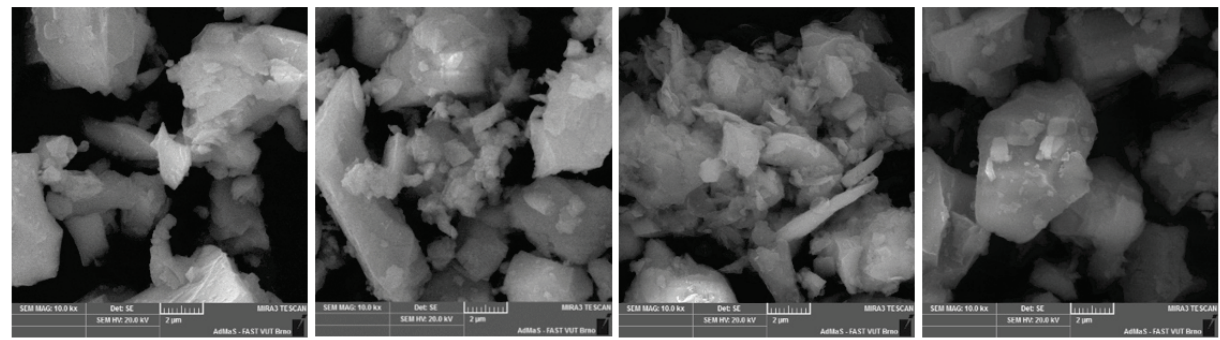

Obr. 1 Snímky ze SEM zleva: STR (a), VÁP 7 (b), ZAR (c), BK (d).

Tab. 1 Vstupní parametry použitých příměsí.

\begin{tabular}{cccccc}
\hline Surovina & STR & VÁP 7 & VÁP 9 & ZAR & BK \\
\hline Měrná hmotnost $\left[\mathbf{k g} / \mathbf{m}^{3}\right]$ & 2920 & 2770 & 2750 & 2780 & 2680 \\
Měrný povrch $\left[\mathbf{c m}^{2} / \mathbf{g}\right]$ & 3840 & 3120 & 4490 & 2320 & 3350 \\
\hline
\end{tabular}

Pro dosažení maximální hutnosti cementové matrice bylo použito speciálního algoritmu sestaveného dle výzkumné práce T. Reschke [7]. Tento algoritmus na základě granulometrie jednotlivých surovin dokáže stanovit nejvhodnější objemový poměr mísení př́měsí pro získání co nejnižší mezerovitosti této kombinace. V př́ípadě, že nebyl nalezen optimální poměr, jak je tomu např́klad při kombinaci STR a mikromletého vápence 7, byl zvolen objemový poměr mísení 50\% : 50\%. Nenalezení optimálního poměru mísení těchto surovin je dáno 
jejich podobnou granulometrií. Výrazně blízká vzájemná granulometrie má za následek, že jakékoliv jejich mísení obecně zhoršuje mezerovitost směsi, která by byla nejnižší pouze při použití jednoho druhu př́měsi. Veškeré objemové dávkování kombinací př́měsí a vypočtené mezerovitosti, potažmo maximální hutnosti tohoto systému jsou znázorněny na Obr. 2 a pro přehlednost jsou také uvedeny v Tab 2.
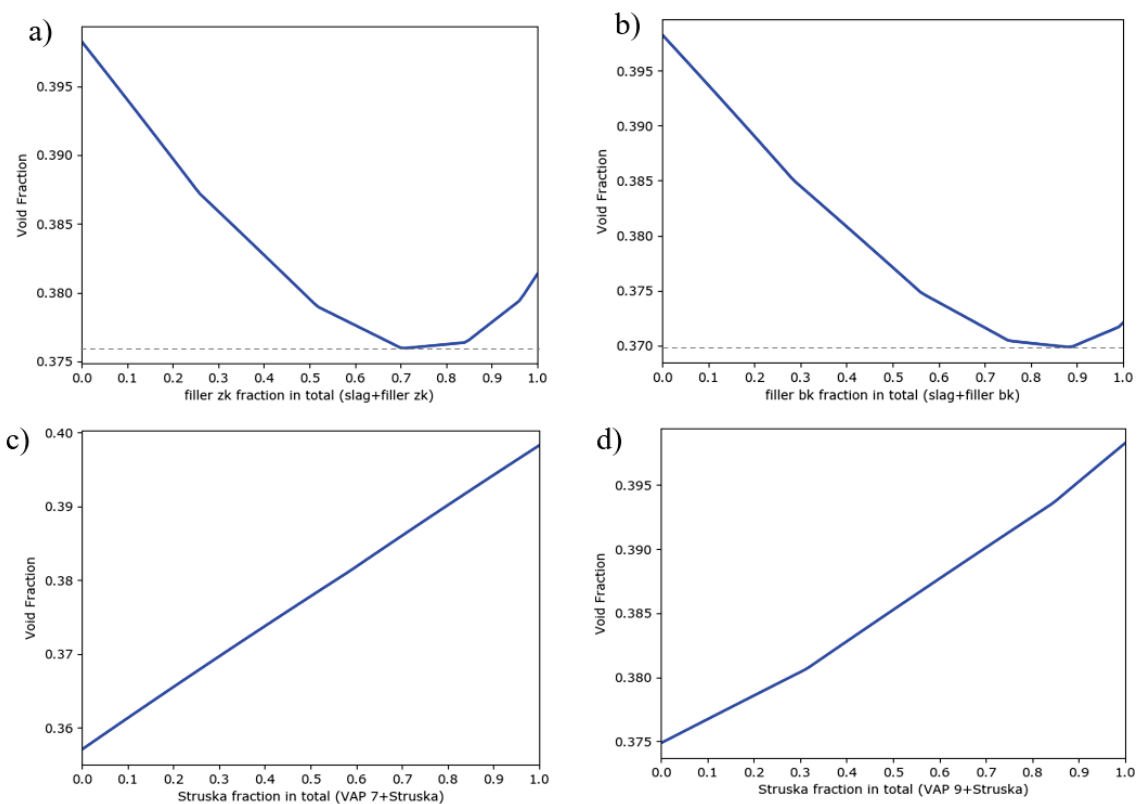

Obr. 2 Optimální poměr mísení STR s kamennými fillery ZAR (a), BK (b) a mikromletými vápenci VÁP 7 (c) a VÁP 9 (d).

Tab. 2 Objemový poměr mísení příměsí pro dosažení maximální hutnosti v suchém stavu.

\begin{tabular}{ccccccccc}
\hline $\begin{array}{c}\text { Druh a } \\
\text { množství } \\
\text { př́měsi [\% } \\
\text { obj.] }\end{array}$ & STR & ZAR & BK & VÁP 7 & VÁP 9 & $\begin{array}{c}\text { Maximální } \\
\text { hutnost [\%] }\end{array}$ & $\begin{array}{c}\text { Měrná } \\
\text { hmotnost } \\
{\left[\mathbf{k g} / \mathbf{m}^{3}\right]}\end{array}$ & $\begin{array}{c}\text { Měrný } \\
\text { povrch } \\
{\left[\mathbf{c m}^{2} / \mathbf{g}\right]}\end{array}$ \\
\hline STR + ZAR & 27 & 73 & - & - & - & 62,40 & 2820 & 2760 \\
STR + BK & 10 & - & 90 & - & - & 63,01 & 2710 & 3400 \\
STR + VÁP 7 & 50 & - & - & 50 & - & - & 2850 & 3480 \\
STR + VÁP 9 & 50 & - & - & - & 50 & - & 2830 & 4165 \\
\hline
\end{tabular}

\section{METODIKA}

V rámci experimentální části bylo navrženo celkem 9 receptur betonů pevnostní třídy C 30/37. Pět receptur obsahující pouze jeden druh príměsi a zbývající čtyři receptury kombinaci VJMGS s příměsí inertní v poměru stanoveném výpočtovým algoritmem. Jako cement byl použit CEM I 42,5 R z cementárny Mokrá. Jeho množství $\mathrm{v}$ jednotlivých recepturách př́měsí bylo upraveno tak, aby byla dosažena přibližně srovnatelná pevnost betonového kompozitu po 28 dnech normového zrání při shodné konzistenci. Množství příměsi v recepturách bez jejich vzájemné kombinace bylo $120 \mathrm{~kg} / \mathrm{m}^{3}$. Následná kombinace inertní příměsi s VJMGS probíhala dle Tab. 2. Aby se zamezilo ovlivnění mechanických parametrů vlivem rozdílné skladby směsi kameniva, byla pro veškeré receptury navržena shodná křivka zrnitosti směsi kameniva. Pro dosažení shodné konzistence všech receptur stanovené metodou sednutím kužele dle ČSN EN 12350 - 2 [8] s hodnotou cca 180 mm v čase 5 minut, se množství záměsové vody $\mathrm{v}$ betonové směsi pohybovalo v rozmezí $175 \mathrm{l} / \mathrm{m}^{3}-1801 / \mathrm{m}^{3}$ a množství superplastifikační přísady Mapei Dyna mon SX 14 v rozmezí 4,0 - 4,7 kg/m³. Hodnota vodního součinitele byla vypočtena jako poměr hmotnosti vody $\mathrm{k}$ celkové hmotnosti cementu a př́měsí bez ohledu na k-hodnotu dle ČSN EN 206+A2 [3]. Přesné složení jednotlivých betonových receptur je uvedeno v Tab 3. 
Tab. 3 Složení betonových receptur.

\begin{tabular}{cccccccccc}
\hline $\begin{array}{c}\text { Receptura/Surovina } \\
{\left[\mathbf{k g} / \mathbf{m}^{3}\right]}\end{array}$ & \multirow{2}{*}{ STR } & \multirow{2}{*}{ ZAR } & \multirow{2}{*}{ BK } & VÁP 7 & VÁP 9 & $\begin{array}{c}\text { STR + } \\
\text { ZAR }\end{array}$ & $\begin{array}{c}\text { STR + } \\
\text { BK }\end{array}$ & $\begin{array}{c}\text { STR + } \\
\text { VÁP 7 }\end{array}$ & $\begin{array}{c}\text { STR + } \\
\text { VÁP 9 }\end{array}$ \\
\hline CEM I 42,5 R, Mokrá & 300 & 315 & 315 & 315 & 315 & 300 & 300 & 300 & 300 \\
STR Dětmarovice & 90 & - & - & - & - & 25 & 10 & 46 & 46 \\
Filler Zárubka & - & 120 & - & - & - & 65 & - & - & - \\
Filler Bílý Kámen & - & - & 120 & - & - & - & 80 & - & - \\
Vápenec 7 Mokrá & - & - & - & 120 & - & - & - & 44 & - \\
Vápenec 9 Mokrá & - & - & - & - & 120 & - & - & - & 443 \\
DTK 0/4 Hrušovany & 765 & 730 & 730 & 735 & 735 & 760 & 760 & 760 & 760 \\
HTK 4/8 Hrušovany & 240 & 230 & 235 & 235 & 235 & 240 & 240 & 240 & 235 \\
HDK 8/16 Želešice & 475 & 470 & 470 & 470 & 470 & 475 & 475 & 475 & 475 \\
HDK 11/22 Želešice & 365 & 355 & 360 & 360 & 360 & 365 & 365 & 365 & 365 \\
$\quad$ Voda & 175 & 180 & 175 & 175 & 175 & 175 & 175 & 175 & 178 \\
Mapei Dynamon SX 14 & 4,1 & 4,7 & 4,0 & 4,2 & 4,3 & 4,5 & 4,0 & 4,5 & 4,5 \\
Vodní součinitel & 0,45 & 0,41 & 0,40 & 0,40 & 0,40 & 0,45 & 0,45 & 0,45 & 0,46 \\
\hline
\end{tabular}

\section{VÝSLEDKY MĚŘENÍ}

Od každé receptury byly vyrobeny betonové krychle o hraně $150 \mathrm{~mm}$, na kterých byla ve stáří 7, 28 a 90 dní stanovena objemová hmotnost betonu dle ČSN EN 12390 - 7 [9] a dle ČSN EN 12390 - 3 [10] pevnost betonu v tlaku. Fyzikálně-mechanické parametry jednotlivých receptur jsou znázorněny na Obr 3 . Uváděná průměrná hodnota pevnosti betonu v tlaku byla vždy stanovena na 5 zkušebních tělesech v daném stárí.

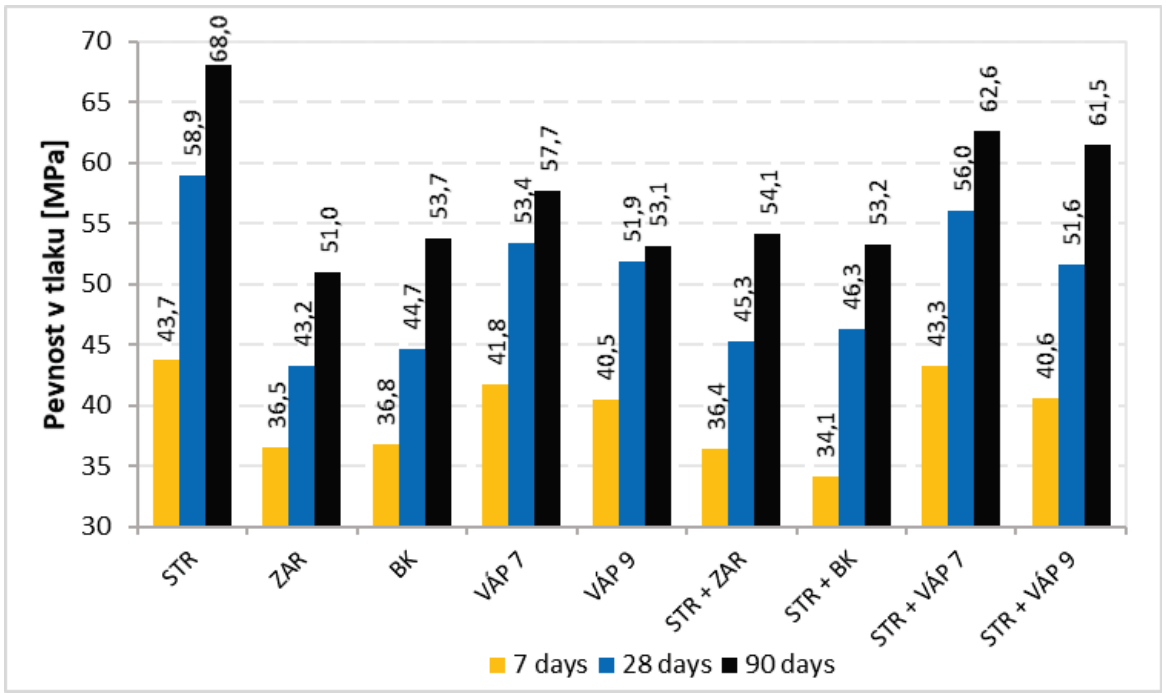

Obr. 3 Fyzikálně-mechanické parametry jednotlivých receptur ve stáří 7, 28 a 90 dní.

Jak znázorňuje Obr. 3, nejvyšší pevnost betonu v tlaku po 7 dnech normového zrání vykazuje betonová směs STR, 43,7 MPa. Velice obdobné pevnosti betonu v tlaku po 7 dnech zrání vykazovaly také betonové směsi v kombinaci STR s mikromletými vápenci. V případě směsi STR + VÁP 7 byly získány téměř totožné fyzikálněmechanické parametry. Je nutné ovšem připomenout, že tyto směsi obsahovali pouze poloviční dávku VJMGS v porovnání s betonovou směsí vykazující nejvyšší fyzikálně-mechanické parametry. Je možno se domnívat, že získání takovýchto pevností bylo způsobeno tzv. skrytou aktivitou vápenců, kdy jemné částice tvoří krystalizační zárodky, na které se mohou reakční produkty slínku vysrážet Nejnižší pevnost betonu v tlaku po 7 dnech zrání vykazovala betonová směs STR + BK, 34,1 MPa.

Po 28 dnech normového zrání vykazovala nejvyšší pevnost betonu v tlaku betonová receptura STR 58,9 MPa. Velice dobré pevnosti betonu v tlaku vykazovaly opět betonové směsi obsahující kombinace STR 
a mikromletých vápenců. Naopak nejnižší pevnost betonu v tlaku (43,2 MPa) po 28 dnech zrání vykazovala směs s př́měsí kamenného filleru z lokality Zárubka. Dle složení této receptury je ovšem patrné, že vlivem nepravidelnosti a zvýšené nasákavosti zrn kamenného filleru vyžadovala tato směs jednu z největších dávek záměsové vody i superplastifikační přísady.

Dle získaných hodnot pevností betonu v tlaku jednotlivých směsí lze konstatovat, že veškeré receptury splňují požadovanou pevnostní třídu C30/37.

Nejvyšší fyzikálně-mechanické po 90 dnech zrání vykazovala betonová směs STR - 68,0 MPa. Velmi dobré pevnosti betonu v tlaku vykazovaly také betonové směsi s kombinací př́měsí STR a mikromletým vápencem 7 i 9. V porovnání s recepturami obsahující pouze mikromletý vápenec 7 či 9 došlo k poměrně výraznému zvýšení mechanických parametrů. Lze tedy konstatovat, že kombinace mikromletého vápence $\mathrm{s}$ aktivní př́měsí má pozitivní vliv na mechanické parametry betonové směsi a tato kombinace aktivní příměsi s příměsí inertní se jeví velice zajímavě. Nejnižší pevnost betonu v tlaku (51,0 MPa) vykazovala receptura s kamenným fillerem z lokality Zárubka. Při kombinaci tohoto kamenného filleru s aktivní př́měsí ovšem došlo ke zvýšení mechanických parametrů směsi, a proto lze kombinaci aktivních a pasivních příměsí považovat za výhodnou z hlediska zvýšení mechanických parametrů směsi.

\section{EKONOMICKÉ ZHODNOCENÍ}

Vhodná kombinace aktivní příměsi $\mathrm{s}$ prríměsí inertní se $\mathrm{v}$ některých př́ípadech jeví z hlediska dosažení obdobných fyzikálně-mechanických parametrů porovnávaných směsí jako velice zajímavá. Zda by se jejich kombinace jevila výhodně i z ekonomického hlediska, je možné sledovat na Obr. 4, kde je zobrazen poměr hmotnosti VJMGS a pevnosti betonu v tlaku pro jednotlivé receptury obsahující VJMGS či její kombinaci $\mathrm{s}$ inertní př́íměsí. Vzhledem ke zvyšující se poptávce po tomto druhu aktivní př́íměsi a jeho nedostatku z důvodu uzavíraní vysokých pecí či ekonomické náročnosti z důvodu mletí se dá předpokládat další zvyšování ceny této komodity. Proto při nižším poměru se dá predikovat nižší množství VJMGS ve směsi, což by se mělo pozitivně projevit na nákladech na vstupní suroviny. Obsah cementu v porovnávaných recepturách je konstantní a použité příměsi jsou vyjma VJMGS z normativního hlediska považovány za inertní. Fyzikálně-mechanické parametry by tedy měly být ovlivněny primárně obsaženou dávkou VJMGS v dané receptuře.

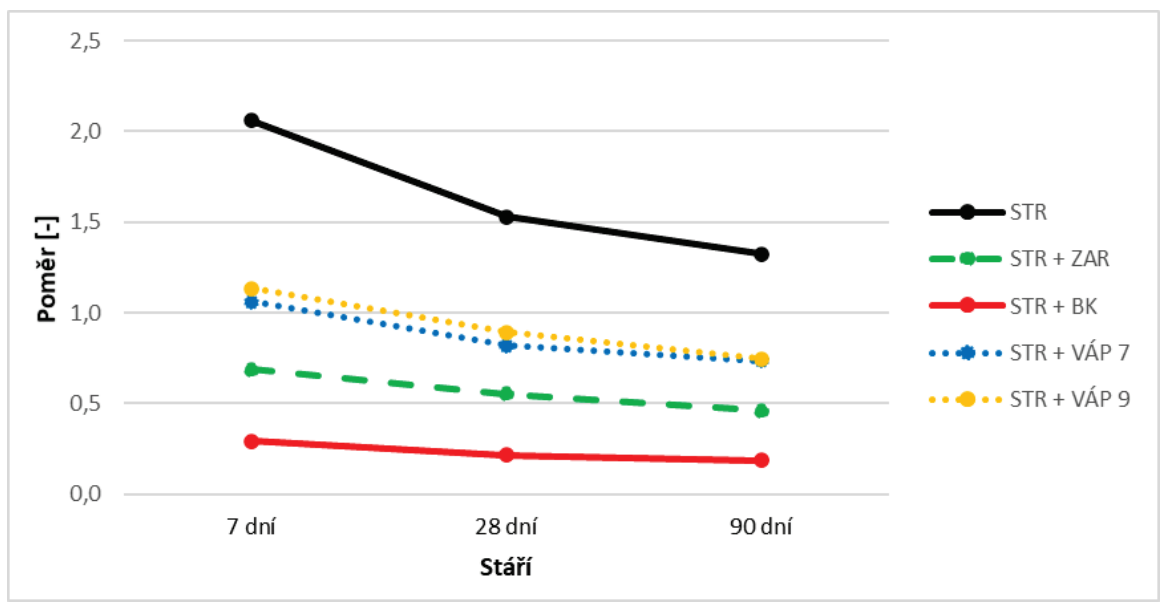

Obr. 4 Poměr hmotnosti STR k fyzikálně-mechanickým parametrům betonového kompozitu.

V prŕípadě betonové směsi obsahující pouze STR lze pozorovat, že poměr celkové hmotnosti STR k dosaženým fyzikálně-mechanickým parametrům je nejvyšší, což může nasvědčovat o nepř́liš efektivním využívání tohoto druhu př́měsi vzhledem $\mathrm{k}$ jejím vysokým dávkám a dosaženým pevnostem betonu v tlaku. V důsledku vytvrzování betonového kompozitu a tvorbě novotvarů lze pozorovat, ostatně jako u veškerých receptur, snižující se trend dané křivky, z důvodu navyšování fyzikálně-mechanických parametrů. Při kombinaci STR s mikromletými vápenci či kamennými fillery, dochází v důsledku nižší dávky aktivní příměsi k dosažení nižšího poměru, což by mohlo nasvědčovat o efektivnějším využití aktivní př́iměsi. Při porovnání fyzikálněmechanických parametrů betonové směsi STR a fyzikálně-mechanických parametrů betonové receptury s kombinací STR a VÁP 7 či receptury s kombinací STR a VÁP 9 bylo dosaženo velice obdobných hodnot, ovšem při poloviční dávce aktivní př́iměsi ve směsi. Tyto výsledky poukazují na možný směr moderního návrhu 
betonové směsi s optimálním využitím všech pozitiv jednotlivých druhů příměsí. V případě betonových receptur obsahujících kombinaci aktivní prríměsi a kamenných fillerů byla dávka VJMGS ve směsi velice nízká, proto se může vzhledem k nejnižšímu poměru jako nejvhodnější varianta. Ovšem s přihlédnutím na dosažené fyzikálně-mechanické parametry je nutné konstatovat, že by v technické praxi muselo dojít k úpravě receptury, např. zvýšením množství cementu ve směsi a zvýšení dávky plastifikační přísady, aby byly získány vyšší fyzikálně-mechanické parametry. Tudíž se jako nejvhodnější varianta jeví kombinace STR s mikromletými vápenci.

\section{ZÁVĚR}

Studie se zabývá kombinací VJMGS s inertní příměsí v optimálním poměru mísení s cílem dosáhnout co nejnižší mezerovistosti cementové matrice. Snížení mezerovitosti, potažmo zvýšení hutnosti cementové matrice, by mělo mít $\mathrm{v}$ důsledku pozitivní vliv nejen na fyzikálně-mechanické parametry, ale také na zvýšení trvanlivosti či odolnosti betonového kompozitu. Zejména v současnosti, kdy je zvýšený tlak na výrobu směsných cementů, a z VJMGS se stává velice obtížně dostupná surovina, se stále zvyšující se cenou, je nutné hledat nové možnosti a alternativy optimalizace složení betonové směsi. Kombinace aktivní př́měsi společně s inertní by mohla být jedna z možných řešení.

Dle získaných výsledků z experimentu lze konstatovat, že nejvyšší fyzikálně-mechanické parametry vykazovala betonová směs obsahující pouze VJMGS. Velice dobré hodnoty pevnosti betonu v tlaku vykazovaly také betonové směsi v kombinaci STR a mikromletých vápenců, u kterých se čím dál více mluví o jejich tzv. skryté aktivitě. Jemné částice tvoří krystalizační zárodky přispívající k vyššímu stupni hydratace slínku. Je nutné také připomenout, že těchto fyzikálně-mechanických parametrů bylo dosaženo s poloviční dávkou aktivní př́měsi v porovnání se směsí obsahující pouze VJMGS. Ze získaných výsledků lze také konstatovat, že téměř ve většině případů došlo při kombinaci aktivní a inertní příměsi ke zlepšení fyzikálně-mechanických parametrů, proto se lze domnívat, že vzájemná kombinace těchto dvou druhů příměsí může být v technické praxi velice přínosná.

Tento provedený experiment je počátkem studie možnosti optimalizace složení betonové směsi a možnosti kombinace aktivní příměsi společně s inertní. Pro další možnosti pozitivního přínosu vzájemné kombinace příměsí, například odolnost vi̊či CHRL či agresivním mediím je nutné provést další množství experimentů a stanovit přesný vliv a možnosti vzájemné kombinace příměsí.

\section{Poděkování}

Př́spěvek byl vytvořen v rámci řešení projektu: FAST-J-21-7431 Posouzení odolnosti betonového kompozitu v chemicky agresivním prostředí za pomocí nedestruktivních metod.

\section{Použité zdroje}

[1] TAO, Jiavin a Xiaosheng WEI. Effect of ground granulated blast-furnace slag on the hydration and properties of cement paste. Advances in Cement Research. 2019, (31), 251-260.

[2] APONTE, Diego Fernando, Marilda BARRA a Enric VÀZQUEZ. Durability and cementing efficiency of fly ash in concretes. Construction and Building Materials. 2012, (30), $537-546$.

[3] ČSN EN 206+A2. Beton - Specifikace, vlastnosti, výroba a shoda. Praha: ÚNMZ, 2021.

[4] OEY, Tandré, Aditya KUMAR, Narayanan NEITHALATH, Gaurav SANT a G SCHERER. The Filler Effect: The Influence of Filler Content and Surface Area on Cementitious Reaction Rates. Journal of the American Ceramic Society. 2013, (Vol. 96), 1978-1990.

[5] MOHAMED, Ashraf Ragab, Mona ELSALAMAWY a Marwa RAGAB. Modeling the influence of limestone addition on cement hydration. Alexandria Engineering Journal. 2015, 10 November 2014, (54).

[6] ŤAŽKÝ, M.; Hela, R. High-Performance Concretes Intended for Deep Foundations of Constructions. Civil Engineering and Architecture, 2020, roč. 8, č. 2, s. 46-54. ISSN: 2332-1091.

[7] RESCHKE, T. Der Einfluss der Granulometrie der Feinstoffe auf die Gefugeentwicklung und die Festigkeit von Beton, Ph.D. Thesis, Weimar, 2000.

[8] ČSN EN 12350-2. Zkoušení čerstvého betonu - Část 2: Zkouška sednutím. Opr.1. Praha: ÚNMZ, 2019.

[9] ČSN EN 12390-7. Zkoušení ztvrdlého betonu: Část 7: Objemová hmotnost ztvrdlého betonu. Opr.1. Praha: ÚNMZ, 2019.

[10] ČSN EN 12390-3. Zkoušení ztvrdlého betonu: Část 3: Pevnost v tlaku zkušebních těles. Opr.1. Praha: ÚNMZ, 2019. 